\title{
Giant Cell-Rich Variant of Extraskeletal Osteosarcoma Above the Patella - A Rare Case Study and Review of the Literature
}

\author{
Thanapon Chobpenthai MD ${ }^{1,2 *}$, Pichaya Thanindratarn MD $^{1}$ \\ ${ }^{1}$ Department of Orthopedics, Chulabhorn hospital, Bangkok, Thailand
}

${ }^{2}$ Faculty of Medicine and Public Health, HRH Princess Chulabhorn College of Medical Science, Chulabhorn Royal Academy, Bangkok, Thailand

*Corresponding author: Thanapon Chobpenthai MD, 906 Kamphaeng Phet 6 Rd., Talat Bang Khen, Lak Si, Bangkok 10210, Thailand

\begin{abstract}
ARTICLE INFO
Received: 晋 July 12, 2019

Published: 慧 July 23, 2019

Citation: Thanapon Chobpenthai MD, Pichaya Thanindratarn MD. Giant CellRich Variant of Extraskeletal Osteosarcoma Above the Patella - A Rare Case Study and Review of the Literature.

ABSTRACT

Background: The giant cell-rich variant of extraskeletal osteosarcoma is a rare subtype of osteosarcoma, occurring in the extremities of adults prevalently in their sixth decade of life. We report an exceptional giant cell-rich variant of extraskeletal osteosarcoma that was detected above the patella in an adolescent patient. The exact histological criteria for giant cell-rich osteosarcoma is not clearly defined, which makes it very challenging to identify the key characteristics for preoperative discrimination between malignant giant cell-rich osteosarcoma and benign soft tissue giant cell tumors. This exceptional case can be a useful example for differential diagnosis of tumors with similar giant cell morphology for further appropriate choices of treatment.
\end{abstract} Biomed J Sci \& Tech Res 19(5)-2019. BJSTR. MS.ID.003369.

Abbreviations: MRI: Magnetic Resonance Imaging; ESOS: Extraskeletal Osteosarcoma; GCRO: Giant Cell-Rich Osteosarcoma; GCR-ESOS: Giant Cell-Rich Variant of Extraskeletal Osteosarcoma

Case Presentation: An 11-year-old Thai girl presented at our hospital with a $10-\mathrm{cm}$ painless swelling in her right knee for three months. On examination, an irregular mass measuring $10 \times 5 \mathrm{~cm} 2$ in size was detected above her right patella bone along with two 4-cm right inguinal lymph nodes. Radiological investigations and MRI showed the heterogeneous soft tissue mass beneath the subcutaneous fat without any patella bone invasion. Histopathology displayed numerous scattered multi-nucleated giant cells among the medium-size round cells to spindle cells in the background, together with osteoid formation. Abnormal mitoses, multi-nucleation and bizarre nuclei were found. One inguinal lymph node out of the two was positive for metastatic sarcoma. Our final diagnosis was giant cell-rich variant of extraskeletal osteosarcoma. The patient underwent neoadjuvant chemotherapy (EURAMOS-1) and a wide resection with a rotational flap. Histopathology reported less than $1 \%$ tumor necrosis. The patient remains alive without local recurrence or distant metastasis during the past 13 months.

Conclusion: Giant cell-rich subtype of extraskeletal osteosarcoma has an extremely rare incidence, as well as considerable variations in histological entities. As a result, it has a very poor prognosis and possesses a high risk of misdiagnosis. Our report illustrates an unprecedented rare case of the giant cell-rich variant of extraskeletal osteosarcoma detected above the patella in an adolescent patient. Using a combination of radiography, magnetic resonance imaging, and histological examination, while carefully noticing all points of the clear cutting-criteria for differential diagnosis proposed in this study, a diagnosis of the giant cell-rich subtype of extraskeletal osteosarcoma can be reached. The preoperative differentiation of this exceedingly rare entity is crucial and needs to be examined by musculoskeletal pathologists for early accurate diagnosis and further effective treatment.

\section{Background}

Extraskeletal osteosarcoma (ESOS), a high-grade malignant mesenchymal soft tissue sarcoma, has a rare incidence of $1-2 \%$ of all soft tissue sarcomas and 2-5\% of overall osteosarcomas. Also, giant cell-rich osteosarcoma (GCRO), which was first described by 
Bathurst et al. [1], is a rare variant of osteosarcoma, which accounts for $1-3 \%$ of conventional osteosarcomas [2-4]. To date, there have been 22 cases of GCRO reported, and the most common sites found are the femur and tibia [5,6]. Only 2 cases of the giant cell-rich variant of extraskeletal osteosarcoma (GCR-ESOS) were found (Table 1). Considering histological appearance, GCRO contains a large number of benign giant cells similar to those found in benign giant cell tumors. Due to its rarity and histologically close resemblance to giant cell tumors, the interpretation of lesions can be easily mistaken for giant cell tumors [7-9]. The GCRO needs to be differenti- ated from benign soft tissue giant cell tumors, due to the different treatment strategies that should be provided to patients between the two neoplasms. Preoperative discrimination between GCRO and other tumors with similar giant cell morphology is essential for giving proper diagnoses and further applying proper choice of treatments. In this study, we first report a giant cell-rich variant of extraskeletal osteosarcoma detected above the patella in an adolescent patient that may mimic benign giant cell tumors. The clear-cutting criteria for preoperative discrimination are also discussed.

Table 1: Previously reported 22 cases of giant cell-rich osteosarcoma (GCRO) and only 2 cases of giant cell-rich variant of extraskeletal osteosarcoma (GCR-ESOS).

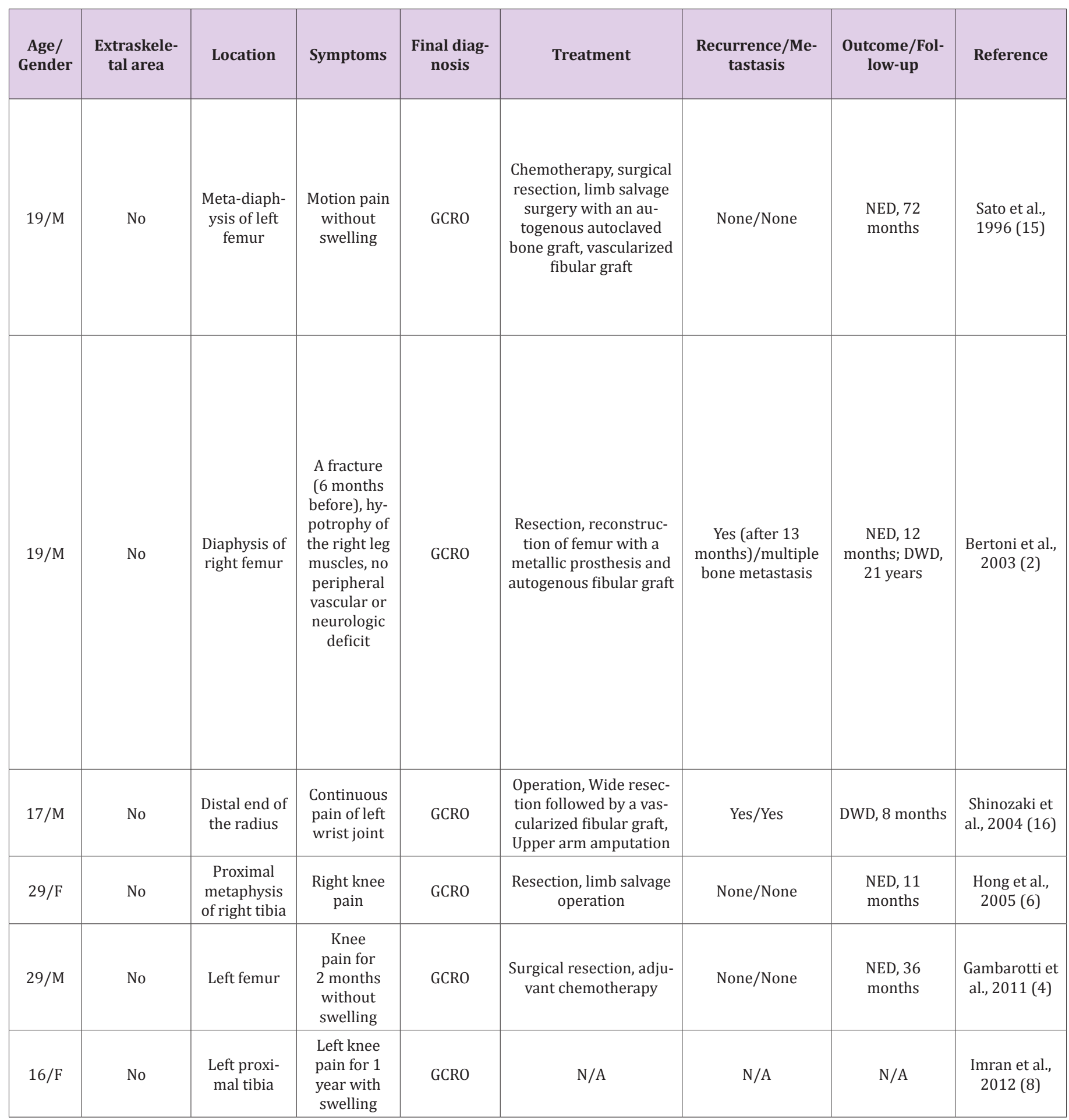




\begin{tabular}{|c|c|c|c|c|c|c|c|c|}
\hline $51 / \mathrm{M}$ & No & $\begin{array}{l}\text { Proximal } \\
\text { femur }\end{array}$ & Pain & GCRO & $\begin{array}{l}\text { Chemotherapy, local } \\
\text { excision with prosthesis } \\
\text { for initial management; } \\
\text { amputation for local } \\
\text { recurrence }\end{array}$ & $\begin{array}{l}\text { Local recurrence/ } \\
\text { Lung }\end{array}$ & $\begin{array}{l}\text { DWD, } 18 \\
\text { months }\end{array}$ & $\begin{array}{l}\text { Wang et al., } \\
2013 \text { (20) }\end{array}$ \\
\hline $18 / \mathrm{M}$ & No & $\begin{array}{l}\text { Proximal } \\
\text { tibia }\end{array}$ & Pain & GCRO & $\begin{array}{l}\text { Amputation and che- } \\
\text { motherapy }\end{array}$ & None/None & $\begin{array}{l}\text { NED, } 92 \\
\text { months }\end{array}$ & $\begin{array}{l}\text { Wang et al., } \\
2013 \text { (20) }\end{array}$ \\
\hline $19 / F$ & No & Distal femur & Pain & GCRO & $\begin{array}{l}\text { Amputation and che- } \\
\text { motherapy }\end{array}$ & None/None & $\begin{array}{l}\text { NED, } 74 \\
\text { months }\end{array}$ & $\begin{array}{l}\text { Wang et al., } \\
2013 \text { (20) }\end{array}$ \\
\hline $16 / \mathrm{M}$ & No & $\begin{array}{l}\text { Proximal } \\
\text { tibia }\end{array}$ & $\begin{array}{l}\text { Pain, palpa- } \\
\text { ble mass }\end{array}$ & GCRO & $\begin{array}{l}\text { Amputation and post- } \\
\text { operative chemother- } \\
\text { apy }\end{array}$ & None/Lung & $\begin{array}{l}\text { DWD, } 20 \\
\text { months }\end{array}$ & $\begin{array}{l}\text { Wang et al., } \\
2013 \text { (20) }\end{array}$ \\
\hline $15 / F$ & No & $\begin{array}{l}\text { Proximal } \\
\text { tibia }\end{array}$ & Pain & GCRO & $\begin{array}{l}\text { Amputation and che- } \\
\text { motherapy }\end{array}$ & None/None & $\begin{array}{l}\text { NED, } 114 \\
\text { months }\end{array}$ & $\begin{array}{l}\text { Wang et al., } \\
2013 \text { (20) }\end{array}$ \\
\hline $32 / \mathrm{M}$ & No & $\begin{array}{l}\text { Proximal } \\
\text { tibia }\end{array}$ & Pain & GCRO & $\begin{array}{c}\text { Preoperative chemo- } \\
\text { therapy }\end{array}$ & $\mathrm{N} / \mathrm{A}$ & AWD, 5 months & $\begin{array}{l}\text { Wang et al., } \\
2013 \text { (20) }\end{array}$ \\
\hline $21 / \mathrm{M}$ & No & Shaft femur & Pain & GCRO & $\begin{array}{l}\text { Chemotherapy and } \\
\text { surgical resection }\end{array}$ & None/N/A & $\mathrm{N} / \mathrm{A}$ & $\begin{array}{c}\text { Kinra et al., } \\
2012 \text { (9) }\end{array}$ \\
\hline $12 / \mathrm{F}$ & No & Distal radius & $\mathrm{N} / \mathrm{A}$ & GCRO & Chemotherapy, surgery & $\begin{array}{l}\text { Local recurrence/ } \\
\text { Metastasis to } \\
\text { unknown site }\end{array}$ & $\begin{array}{l}\text { DOD, } 43 \\
\text { months }\end{array}$ & $\begin{array}{l}\text { Song et al., } \\
2015 \text { (17) }\end{array}$ \\
\hline $19 / F$ & No & Cuneiform & Pain & GCRO & $\begin{array}{c}\text { Chemotherapy, excision } \\
\text { naviculum and three } \\
\text { cuneiforms }\end{array}$ & None/None & $\begin{array}{l}\text { NED, } 36 \\
\text { months }\end{array}$ & $\begin{array}{c}\text { Vijayan et al., } \\
2015 \text { (19) }\end{array}$ \\
\hline $16 / \mathrm{M}$ & No & $\begin{array}{l}\text { Proximal } \\
\text { tibia }\end{array}$ & Pain & GCRO & $\begin{array}{l}\text { Amputation and che- } \\
\text { motherapy }\end{array}$ & None/None & $\begin{array}{l}\text { NED, } 110 \\
\text { months }\end{array}$ & $\begin{array}{c}\text { Chow, } 2016 \\
\text { (3) }\end{array}$ \\
\hline $12 / \mathrm{M}$ & No & $\begin{array}{l}\text { Proximal } \\
\text { fibular }\end{array}$ & $\begin{array}{l}\text { Pain, palpa- } \\
\text { ble mass }\end{array}$ & GCRO & Excisional surgery & $\begin{array}{l}\text { Local recurrence/ } \\
\text { Groin lymph node }\end{array}$ & $\begin{array}{l}\text { DWD, } 21 \\
\text { months }\end{array}$ & $\begin{array}{c}\text { Chow, } 2016 \\
\text { (3) }\end{array}$ \\
\hline $33 / F$ & No & Distal femur & Pain & GCRO & $\begin{array}{l}\text { Chemotherapy and } \\
\text { surgical resection }\end{array}$ & None/None & $\begin{array}{l}\text { NED, } 48 \\
\text { months }\end{array}$ & $\begin{array}{c}\text { Chow, } 2016 \\
\text { (3) }\end{array}$ \\
\hline $15 / F$ & No & $\begin{array}{l}\text { Proximal } \\
\text { tibia }\end{array}$ & Pain & GCRO & $\begin{array}{l}\text { Chemotherapy and } \\
\text { surgical resection }\end{array}$ & None/None & $\begin{array}{l}\text { NED, } 38 \\
\text { months }\end{array}$ & $\begin{array}{c}\text { Chow, } 2016 \\
\text { (3) }\end{array}$ \\
\hline $31 / \mathrm{F}$ & No & $\begin{array}{l}\text { First meta- } \\
\text { tarsal }\end{array}$ & $\begin{array}{l}\text { Palpable } \\
\text { mass }\end{array}$ & GCRO & $\begin{array}{l}\text { Amputation and che- } \\
\text { motherapy }\end{array}$ & None/Iliac & $\begin{array}{l}\text { NED, } 30 \\
\text { months }\end{array}$ & $\begin{array}{c}\text { Chow, } 2016 \\
\text { (3) }\end{array}$ \\
\hline $15 / M$ & No & Distal femur & Pain & GCRO & $\begin{array}{l}\text { Chemotherapy and } \\
\text { surgical resection }\end{array}$ & None/None & $\begin{array}{l}\text { NED, } 12 \\
\text { months }\end{array}$ & $\begin{array}{c}\text { Chow, } 2016 \\
\text { (3) }\end{array}$ \\
\hline $16 / \mathrm{M}$ & No & Mandible & $\begin{array}{l}\text { Pain and } \\
\text { numbness } \\
\text { lower lip }\end{array}$ & GCRO & Surgical resection & None/None & $\begin{array}{l}\text { NED, } 11 \\
\text { months }\end{array}$ & $\begin{array}{c}\text { Chow, } 2016 \\
\text { (3) }\end{array}$ \\
\hline $62 / F$ & Yes & $\begin{array}{l}\text { Parotid } \\
\text { gland }\end{array}$ & Jaw swelling & GCR-ESOS & Excisional surgery & $\mathrm{N} / \mathrm{A}$ & $\mathrm{N} / \mathrm{A}$ & $\begin{array}{c}\text { Huang et al., } \\
2016(7)\end{array}$ \\
\hline $70 / F$ & Yes & $\begin{array}{l}\text { Small intes- } \\
\text { tine }\end{array}$ & $\begin{array}{l}\text { Pain, palpa- } \\
\text { ble mass }\end{array}$ & GCR-ESOS & $\begin{array}{l}\text { Chemotherapy and } \\
\text { surgical resection }\end{array}$ & None/None & DWD, 2 months & $\begin{array}{c}\text { OH and } \\
\text { Chang, } 2017 \\
\text { (13) }\end{array}$ \\
\hline
\end{tabular}

$\mathrm{NED}=$ no evidence of disease; $\mathrm{DOD}=$ died of other disease; $\mathrm{DWD}=$ died with disease; $\mathrm{AWD}=$ alive with disease .

\section{Case Presentation}

An 11-year-old Thai girl presented with a painless swelling (Figure1) in the right knee for three months. She was eventually diagnosed with a giant cell-rich variant of extraskeletal osteosarcoma. On examination, a 10-cm irregular mass was detected over the right patella along with two $4-\mathrm{cm}$ right inguinal lymph nodes. Radiological investigations showed no bone lesion (Figure 2) and bone scintigraphy also displayed no bone metastases. The magnetic resonance imaging (MRI) of the right knee displayed heteroge- neous soft tissue mass beneath the subcutaneous fat without any patella bone invasion (Figure 3). According to the pelvic MRI scan, the MR images showed two enlarged lymph nodes which displayed similar intensity to the soft tissue above the patella, postulating that the two lymph nodes might be positive for malignancy (Figure 4), although histological evidence obtained afterwards suggested that only one lymph node out of the two was indeed positive for metastatic sarcoma. Preoperative open biopsy of the soft tissue above the patella was performed, and the soft tissue was examined by musculoskeletal pathologists. 


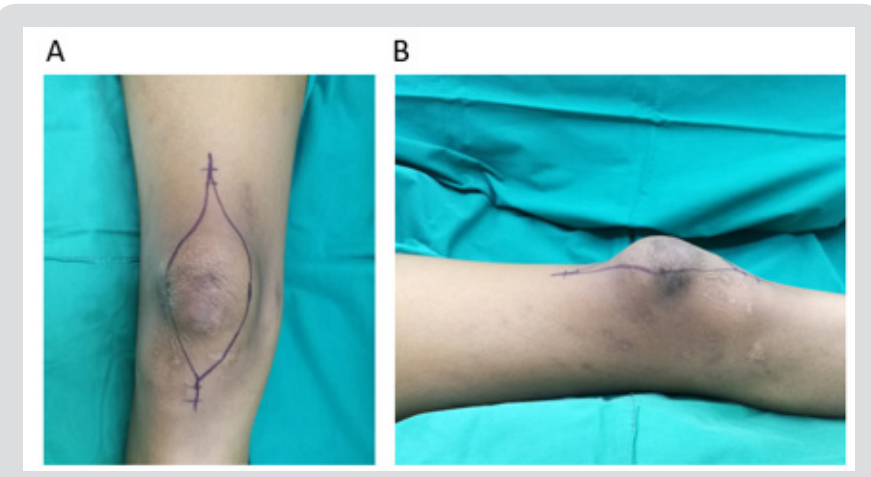

Figure 1:

a. Soft tissue mass above the patella bone in the axial plane and

b. The coronal plane.

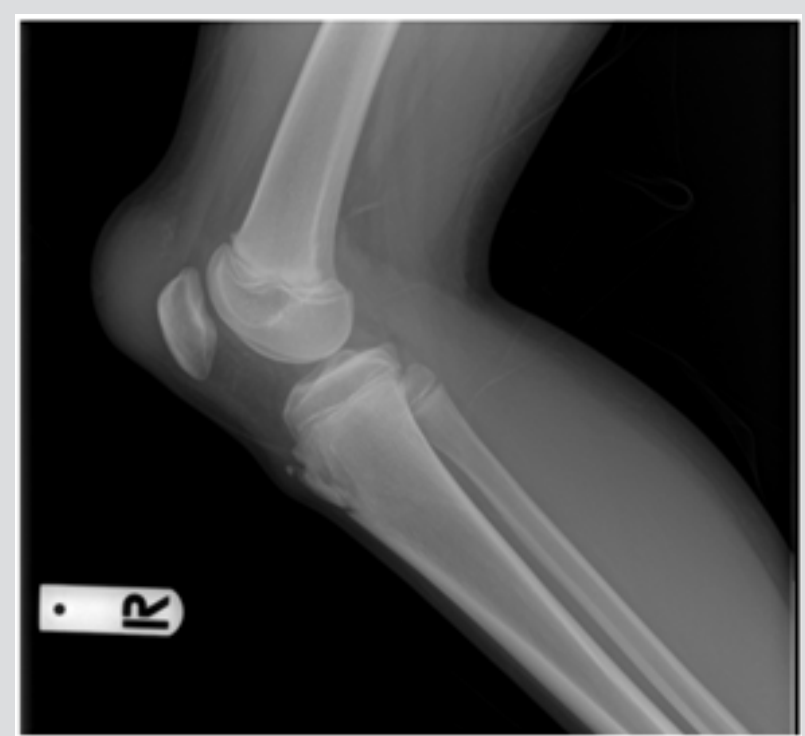

Figure 2: Radiograph shows the shadow of soft tissue above the patella with minimal mineralization.
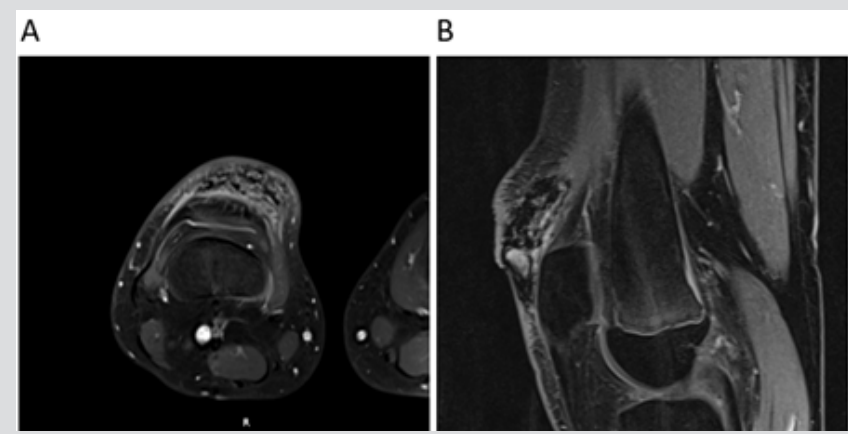

Figure 3:

a. Axial T1-weighted and

b. Sagittal T2-weighted MR Images display soft tissue sarcoma without connection to the patella bone.

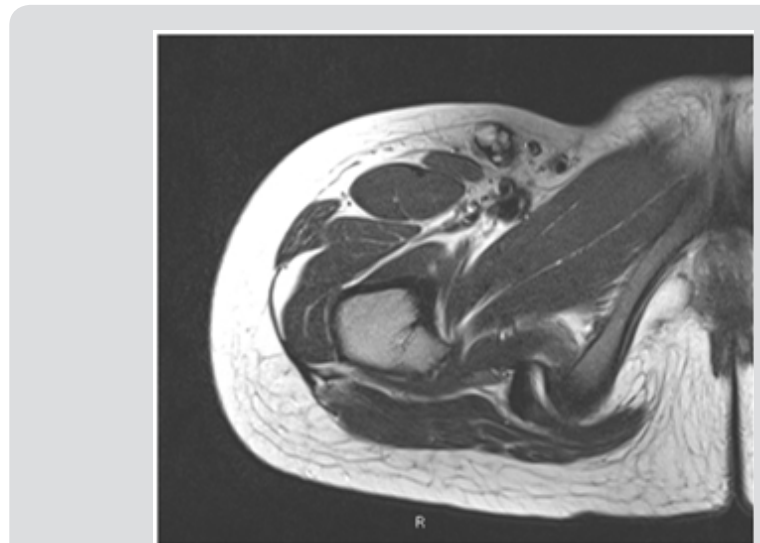

Figure 4: MRI illustrates metastatic lymph node positive on T2-weighted MR Image.

Histopathology showed numerous scattered multi-nucleated giant cells among the medium-size round cells to spindle cells in the background, along with the osteoid matrix (Figure 5). As a result, the final diagnosis was a giant cell-rich variant of extraskeletal osteosarcoma (GCR-ESOS). Neoadjuvant chemotherapy, including cisplatin, doxorubicin and methotrexate was given prior to a wide resection with a rotational flap, shown in Figures 6 \& 7 . Histopathology reported less than 1\% tumor necrosis. Adjuvant chemotherapy, including cisplatin, doxorubicin, methotrexate with the addition of ifosfamide, and etoposide was given. The patient remains alive without local recurrence or distant metastasis during the past 13 months Figures $8 \& 9$.
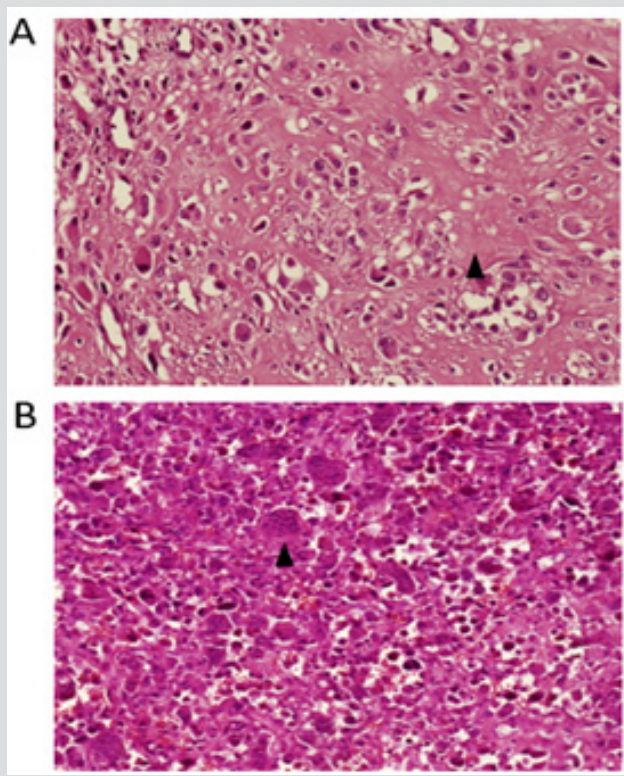

Figure 5:

a. Pathological examination demonstrates the osteogenic sarcoma with malignant osteoid and

b. The area of osteoclast-like giant cells. 


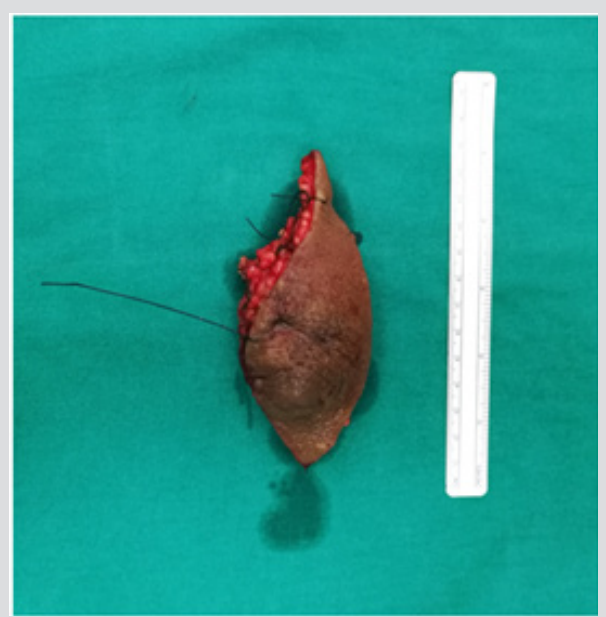

Figure 6: Gross specimen after a wide resection measured $6 \times 13 \mathrm{~cm}$ in size.

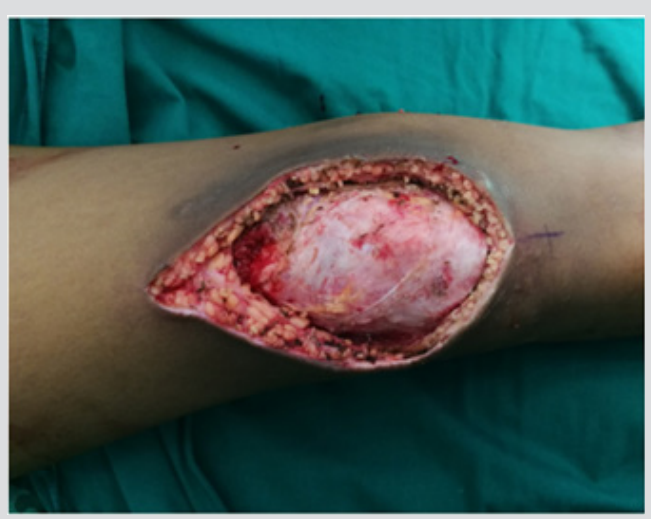

Figure 7: Soft tissue defect at the patellar area after a wide resection for tumor removal.

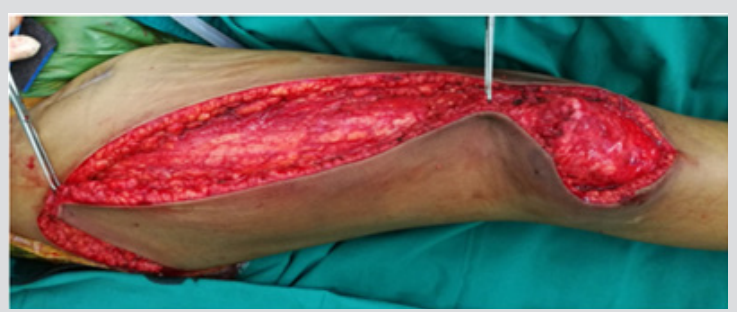

Figure 8: Rotational flap for coverage of the soft tissue defect.

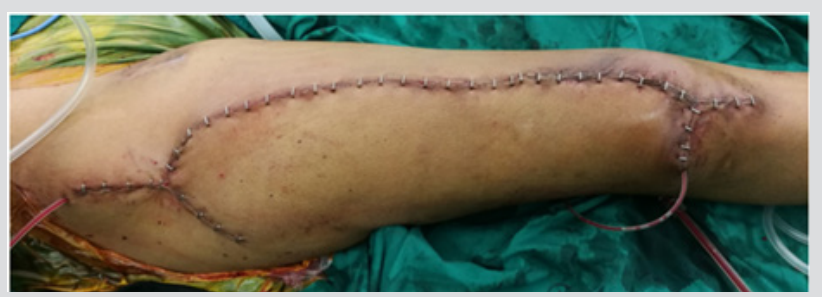

Figure 9: Rotational flap completion and placement of radivac drain.

\section{Discussion and Conclusion}

Giant cell-rich variant of extraskeletal osteosarcoma (GCR-ESOS) is an exceptional subtype of osteosarcoma, considering that it possesses the combined histopathological features of extraskeletal osteosarcoma and giant cell-rich osteosarcoma. The possibility of the occurrence of either extraskeletal osteosarcoma or giant cellrich osteosarcoma alone is rare, below $5 \%$ of overall osteosarcoma occurrence $[2,4,10]$. Our report on the GCR-ESOS, which is the combination of both types of osteosarcoma, is therefore considered extremely rare. Due to this extreme rarity, the GCR-ESOS has a poor prognosis and is easily misdiagnosed, which may lead to inefficient treatment. We thus recommend that the interpretation of lesions should be examined by musculoskeletal pathologists. Considering our case, radiological investigation showed a soft tissue mass with mineralization and without any patella bone attachment. The MRI demonstrated nonspecific T-1 hypointense and T-2 hyperintense lesions.

Differential diagnosis can include any other tumors, such as extraskeletal chondrosarcoma, undifferentiated pleomorphic sarcoma, post-traumatic myositis ossificans, sarcomatoid carcinoma and synovial sarcoma. Histologically, the GCR-ESOS contains numerous osteoclast-like giant cells that may obscure the malignant cells in the background. In such cases, the interpretation of lesions may be mistaken for a benign giant cell tumor. For a reasonable decision concerning treatment, GCR-ESOS needs to be clearly differentiated from benign soft tissue giant cell tumors. We recommend that the GCR-ESOS should be best distinguished by histological features: osteoid formation, atypical mitotic activity and multi-nucleation. Treatment strategies can include a wide resection, or alternatively amputation, which will not cause any difference in overall survival. Adjuvant chemotherapy (Euromos-1) resulted in a 5-year survival rate of $66-77 \%$. Radiation is recommended when the resection is marginal or can be used as a palliative treatment.

In this study we discovered, for the first time, an unusual case of giant cell-rich subtype of osteosarcoma detected above the patella in an adolescent patient. This subtype can be characterized by the striking features of an abundance of osteoclastic giant cells and the paucity of the tumor osteoid. Although it is easily confused by benign soft tissue giant cell tumors, due to its possible overlapped histological features, we suggest clear cutting criteria for preoperative discrimination through the observation of histological structure. From the histological point of view, scattering of osteoclast-like giant cells, extensive spindling, atypical mitotic activity, multi-nucleation, and most importantly osteoid formation are the key characteristics for efficient differential diagnosis. On the side of immunohistochemical analysis, mesenchymal tissue markers such as Vimentin have been noted as a potential diagnostic tool for the GCR-ESOS [11]. while MDM2 and CDK4 can be used to differentiate low-grade osteosarcoma from benign mimics [12, 13-21]. 


\section{Acknowledgement}

We thank Dr. Juthaporn Sangwallek for her kind assistance with manuscript preparation.

\section{References}

1. Bathurst N, Sanerkin N, Path FR, Watt L (1986) Osteoclast-rich osteosarcoma. Br J Radiol 59(703): 667-673.

2. Bertoni F, Bacchini P, Staals EL (2003) Giant cell-rich osteosarcoma. Orthopedics 26(2): 179-181.

3. Chow LTC (2016) Giant cell rich osteosarcoma revisited-diagnostic criteria and histopathologic patterns, Ki67, CDK4 and MDM2 expression, changes in response to biphosphonate and denosumab treatment. Virchows Arch 468(6): 741-755.

4. Gambarotti M, Donato M, Alberghini M, Vanel D (2011) A strange giant cell tumor. Eur J Radiol 77(1): 3-5.

5. Hoch M, Ali S, Agrawal S, Wang C, Khurana JS, et al. (2013) Extraskeletal Osteosarcoma: a case report and review of the literature. Radiology Case $7(7): 15-23$.

6. Hong SJ, Kim KA, Yong HS, Choi JW, Suh SI, et al. (2005) Giant cell-rich osteosarcoma of bone. Eur J Radiol 53(2): 87-90.

7. Huang EC, Ghazikhanian V, Qian X (2016) Giant cell-rich osteosarcoma of the parotid gland: An exceptionally rare entity at an unusual site. Diagn Cytopathol 44(12): 1107-1111.

8. Imran AA, Khaleel ME, Salaria SM, Hasan M (2012) Giant Cell-rich Osteosarcoma: unraveling an elusive enigmatic entity. International Journal of Pathology 10(1): 36-38.

9. Kinra P, Valdamani S, Singh V, Dutta V (2012) Diaphyseal giant cell-rich osteosarcoma: Unusual histological variant in an unusual site. Indian J Pathol Microbiol 55(4): 600-605.

10. Klein MJ, Siegal GP (2006) Anatomic and Histologic Variants. Am J Clin Pathol 125(4): 555-581.

\section{ISSN: 2574-1241}

DOI: 10.26717/BJSTR.2019.19.003369

Thanapon Chobpenthai MD. Biomed J Sci \& Tech Res

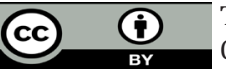

This work is licensed under Creative Commons Attribution 4.0 License

Submission Link: https://biomedres.us/submit-manuscript.php
11. McCarter MD, Lewis JJ, Antonescu CR, Brennan MF (2000) Extraskeletal osteosarcoma: analysis of outcome of a rare neoplasm. Sarcoma 4(3): 119-123.

12. Mirra JM Ed (1989) Bone Tumors: Clinical, Radiologic and Pathologic Correlations. Philadelphia PA: Lea and Febiger.

13. OH SJ, Chang HK (2017) Unusual giant cell-rich variant of extraskeletal osteosarcoma in the mesentery of small intestine. Int J Clin Exp Pathol 10(11): 11225-11229.

14. Rosenberg AE, Heim S (2002) Extraskeletal Osteosarcoma. WHO Classification of Tumors Pathology and Genetics. In: Fletcher CDM, Unni KK, Mertens F, editors. Tumors of Soft Tissue and Bone. Lyon: IARC Press 182-183.

15. Sato K, Yamamura S, Iwata H,Sagiura H, Nagashima N (1996) Giant cellrichosteosarcoma: a case report. Nagoya J Med Sci 59(3-4): 151-157.

16. Shinozaki T, Fukuda T, Watanabe H, Takagishi K (2004) Giant Cell-Rich Osteosarcoma Simulating Giant Cell Tumor of Bone. The Kitakanto Medical Journal 54(2): 147-151.

17. Song WS, Jeon DG, Cho WH, Koh JS, Kong CB, et al. (2015) Giant Cell-Rich Osteosarcoma: A Tumor Simulating Borderline Lesion. J Korean Orthop Assoc 50(3): 225-231.

18. Sun LM, Zhang QF, Tang N, Mi XY, Qiu XS, et al. (2015) Giant cell rich osteosarcoma of the mandible with abundant spindle cells and osteoclast-like giant cells mimicking malignancy in giant cell tumor. Int J Clin Exp Pathol 8(8): 9718-9722.

19.Vijayan S, Naik MA, Hameed SA, Rao SK (2015) Giant cell rich osteosarcoma of the cuneiforms. J Can Res Ther 11(4): 989-992.

20. Wang CS, Yin QH, Liao JS, Lou JH, Ding XY, et al. (2013) Giant cell-rich osteosarcoma in long bones: clinical, radiological and pathological features. Radiol Med 118(8): 1324-1334.

21. Yoshida A, Ushiku T, Motoi T, Shibata T, Beppu Y, et al. (2010) Immunohistochemical analysis of MDM2 and CDK4 distinguishes lowgrade osteosarcoma from benign mimics. Mod Pathol 23(9): 1279-1288.

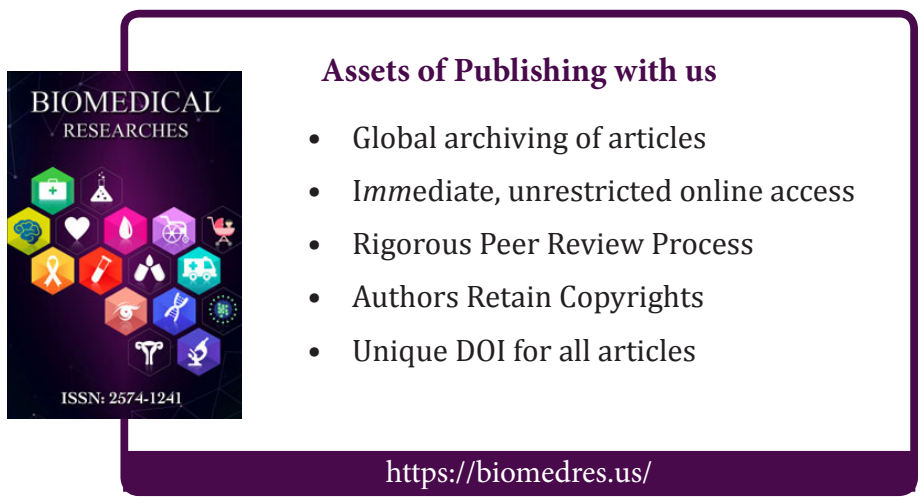

